\title{
Education as An Important Dimension of the Poverty
}

\author{
Msc. Ruzhdie Bici
}

PhD student, Department of Economics, Faculty of Economy, University of Tirana, Albania

Dr. Mirësi Çela

"A. Xhuvani" University, Faculty of Economy, Department of Business - Administration, Elbasan, Albania.

\begin{abstract}
Poverty is an important phenomenon affecting individual and household life. It is important to know the factors that influence the possibility of being poor. An important cause and effect of poverty, one of the ones multidimensional nature of poverty is education level. Mostly, when we speak for the poverty, we based our estimates in the monetary terms, income or consumption. There are other dimensions like education, health, infrastructure, access in basic services, etc, that influence the economic and financial situation of the individuals. In Albania, to calculate the absolute poverty line is used the monetary poverty based on the consumption. The data refers to the Living Standard Measurement Survey (LSMS), which gives us the possibility to have multi indicators and also disaggregate and test the relationship and influence. The main objective of this paper is to analyze the influence of different indicators, mainly related with education and analyzing the influence on the poverty reduction. This research is based on Living Standard Measurement Survey (LSMS). This is a multidimensional survey collected near households and it collects information for living conditions, health, education, poverty, assets, migration etc. Is is used descriptive analyses and multinominal regression to analyse the trend on education and the significance on categories of different factors inluenced the education level. At the end we conclude that education is an influenced factors but also influence the poverty.
\end{abstract}

Keywords: Poverty, UBN, logistic regression, education.

\section{Introduction}

Poverty is a complex phenomenon widespread in the world, which includes different dimensions. Estimation of poverty is based on multidimensional factors, where addition to deprivation of income or consumption, take into consideration other non monetary aspects as: education, health, empowerment, access to basic services and infrastructure. Multi-dimensional way is derived from the capability theory of Amartya Sen and expands the number of dimensions that measure poverty.

Traditional calculation method, takes into account only one variable such as income or consumption. Through monetary poverty an individual is considered poor if family income or consumption is below the poverty line. The poverty line can be relative to the population or absolute. The relative poverty determination of all households below 60 per cent (or below 40 percent) of the median per capita consumption or income are considered poor. The absolute poverty line is fixed in terms of living standards and does not change over time. The poverty measures are poverty headcount, poverty gap and severity. In a dimensional poverty measures poverty line is constructed in such a way that households fall below under poverty line are considered as poor.

An alternative way of calculating the poverty is through multidimensional factors. Multi-dimensional nature of poverty refers to a situation where an individual or family experiencing a certain number of deprivation. These multiple deprivations represent different dimensions (economic welfare, education, health, social exclusion, etc.) of human life. In this paper we will focus more in the education dimension. Education level is influenced by poverty but also is an important dimension of the poverty. 


\section{Methodology}

This research is based on Living Standard Measurement Survey (LSMS). This is a multidimensional survey collected near households and it collects information for living conditions, health, education, poverty, assets, migration etc. The main objective of LSMS is to collect information for the construction and measurement of well-being and to identify the factors that determine it. Total Wellbeing is usually measured by the consumption by providing information on the level and distribution of poverty in the country. LSMS is also a powerful tool for assessing and determining the social costs.

The first LSMS was conducted in 2002. There is a continuity in conducting the survey every three years, respectively in 2005, 2008 and most recently one in 2012. The base of selection was household. It is used the same number of households, the same methodology and the same way of interview of the first three years (around 3600 households). In 2012 the sample was almost double to have a representation and availability of results not only at four regions but also at the country level.

One important module collects information on education. The poverty level in Albania is based on absolute poverty line calculated through consumption. Consumtion is an aggregate variable that take in consideration monetary and non monetary deprivations. An individual based on monetary poverty is considered as poor if his level of per capita consumption falls under poverty line. Non monetary poverty is based on deprivation. We will consider an household as poor if they do not meet a certain basic needs. Based on INSTAT definition it is calculated an index where an individual is considered as poor if two or more of the basic needs (two or more NBP) are unmet (POOR) and as extremely poor when they are not completed three or more (three or more NBP) basic needs (EPOOR). This index is constructed through five indicators where education of the head is one the dimensions. Indirectly, the educatotion level of the head (parents education) inlfuence the education level the individuals.

This five indicators are coded:

(X1) - It is coded with '1' if the households respond that do not have sanitation and running water in the dwelling '1'.

(X2) - If the dwelling have not good condition '1'.

(X3) - If there is no eletricity or have interruptions for more than six hours per day ' 1 '.

(X4) - If there are three or more persons per room it is coded ' 1 '.

(X5) - If the individual lives in a household where the head has only basic education '1'.

We use multinominal logistic model to analyze non-monetary poverty and other factors influencing education level.

\section{Analysis and interpretation of results}

Analysis and interpretation of influential factors and determinants of education level can help understanding education as a risk factor on poverty but also other factors that influence low education level. Non monetary poverty is an important factors with long term effectsLack of water and sanitation not only causes health problems, but also weakens the ability to earn income and / or develop human capital (reflected that to the ability to learn or to attend school). Not having electricity supplies influences the profitable productive investment, this influences having lower economic growth as long-term effects.

Non-monetary poverty is significantly lower than the monetary poverty (absolute), $11.5 \%$ compared with $14.3 \%$. Nonmonetary poverty in rural area is at a significant difference and higher than in Urban area. By region poverty is higher in the Mountain region, and in the Central. Urban Tirana (the capital of Albania) has the lowest level of non-monetary poverty $(5.9 \%)$, and this is connected with more access to basic services.

Figure 1: Monetary and non monetary poverty by prefecture 


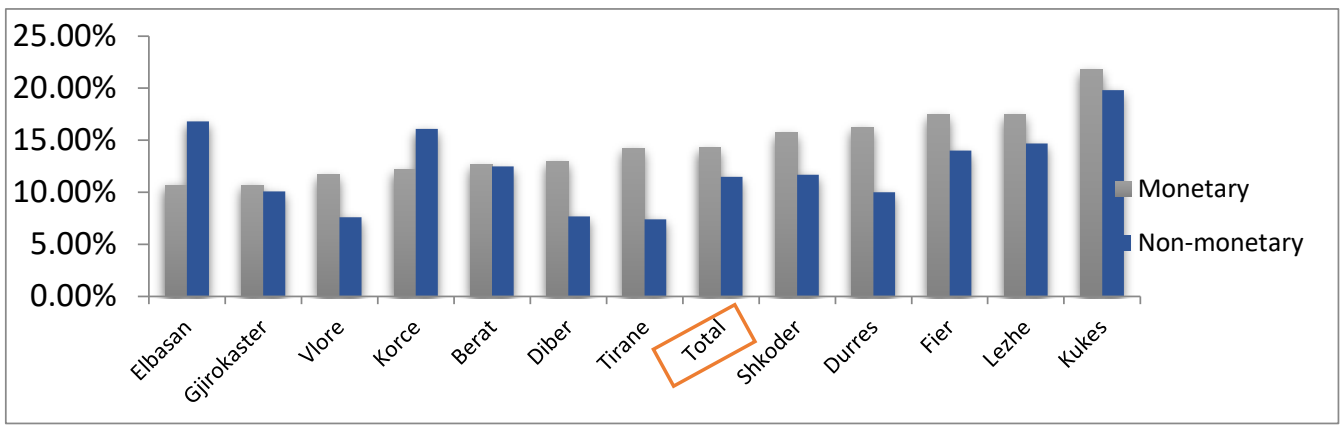

Source: LSMS 2012

What is interesting and can be seen in Figure 1 above is that in the prefectures of Gjirokastra and Berat monetary and nonmonetary poverty are almost the same. Non-monetary poverty is higher than the monetary poverty to the prefectures of Korce and Elbasan. Other prefectures have a noticeable difference and significantly higher monetary poverty compared with non monetary poverty.

Non-monetary poverty is more widespread in the prefectures of Kukes, Elbasan, Berat, Korca compared to the national average. Tirana, Vlora, Dibra, Durres are prefectures ${ }^{1}$ that have lower levels of non-monetary poverty. Always are poor households that suffer from lack of infrastructure and resources to provide special services. Even when the same view is also for the water supply. If we compare poor households compared with those not poor, most poor people have no running water in the dwelling. They try to provide water from springs, wells or trucks.

There are several influencing factors that lead to a vicious cycle of remaining in poverty as education, health, lifestyle. The risk of being poor is also influenced by education level or being educated. A less educated person is more poor and a poor person have less chances to be educated.

\section{Education as an important determinants of poverty}

Education is an important indicator and one of the dimensions that helps to define the non monetary poverty index through calculating the education of the head. Sometimes these figures are influenced by the methodology and by the traditional to define the head of the household. In this way the head could be the older male person, but not definitely the persons that contribute more to the socio economic household situation. Individuals living in Tirana have a higher level of education of household head compared with other regions.

The right to education is a principle ensured by the Constitution of the Republic of Albania, which ensures equality before the law and freedom from discrimination on the basis of race, gender, ethnicity and language 2 . In the field of education is intended to increase children's access to all levels of education and the facilitation of procedures for inclusion in education. To this have been undertaken a number of reforms, legislative, administrative structure in the field of social services, health care, education, culture and the protection of children's rights.

As lower is the education level, higher is the percentage of poverty people for individuals 21 years old and higher. This trend is visible for Tirana and other regions.

Table 1: Poverty by education level

\begin{tabular}{|l|l|l|l|l|}
\hline \multirow{4}{*}{$\begin{array}{l}\text { Highest diploma for population aged } 21 \text { years old } \\
\text { and over }\end{array}$} & Tirana & Other urban & Rural & Total \\
\hline None & $23.5 \%$ & $22.6 \%$ & $14.7 \%$ & $18.1 \%$ \\
\hline Basic education (4/5 years) & $12.7 \%$ & $12.2 \%$ & $16.1 \%$ & $14.5 \%$ \\
\hline Lower secondary (8/9 years) & $22.5 \%$ & $16.9 \%$ & $13.7 \%$ & $15.7 \%$ \\
\hline
\end{tabular}

1 Prefecture is NUTS 3 classification 


\begin{tabular}{|l|l|l|l|l|}
\hline Higher secondary & $8.5 \%$ & $11.0 \%$ & $12.3 \%$ & $10.7 \%$ \\
\hline Vocational 2 / 3 years & $9.7 \%$ & $8.4 \%$ & $12.4 \%$ & $9.5 \%$ \\
\hline Vocational 4 / 5 years & $2.6 \%$ & $4.8 \%$ & $4.8 \%$ & $4.5 \%$ \\
\hline University or higher & $3.3 \%$ & $3.8 \%$ & $6.0 \%$ & $4.0 \%$ \\
\hline \hline Total & $10.7 \%$ & $12.0 \%$ & $13.0 \%$ & $12.2 \%$ \\
\hline
\end{tabular}

Source: LSMS 2012

The Social Inclusion Cross-Cutting Strategy aimed access to preschool and basic obligatory level for all children by 2015. In this context, further measures are taken to increase the enrollment rate in primary education, especially for children in rural areas, particularly girls, a necessary condition to meet in this way a priority in the Millennium Development Goals of the UN and the European Partnership.

Being or not with a higher level of education is a social factor that influences not only in finding a good and well paid job, but also on the concept of the individual for a better life, not isolated, to get a good health care, although average schooling etc. Mean years of schooling have been increased nationally as well as by regions but still remain at low levels (currently $10.3 \%$ for the population aged 21 and above from $9.2 \%$ that has been in 2008 and $8.5 \%$ in 2002). The mean years of school is 10.3 in 2012 increased by almost by 2 years from 2002. Rural area remains less educated commpared with urban area and Tirana. This difference is significantly higher in 2012, Tirana (12.3\%) compared with rural area (8.9\%).

Table 2: Mean years of school for population age 21 years old and over

\begin{tabular}{|c|c|c|c|c|}
\hline \multirow[t]{2}{*}{ Survey year } & \multicolumn{4}{|c|}{ Mean years of school for population age 21 years old and over } \\
\hline & Tirana & Other Urban & Rural & Total \\
\hline 2002 & 10.9 & 9.5 & 7.4 & 8.5 \\
\hline 2005 & 11 & 9.9 & 7.8 & 8.9 \\
\hline 2008 & 11.3 & 10 & 7.7 & 9.2 \\
\hline 2012 & 12.3 & 10.7 & 8.9 & 10.3 \\
\hline
\end{tabular}

Source: LSMS 2002, 2005, 2008, 2012

Bearing the Financial costs of education: It is an indisputable fact that the level of income has a great impact on education at the national level, but also to each individual.

The shares of the expenses for education of total per capita consumption show the greatest increase since 2002 compared to other items. The average cost for a person in Albania in 2002 was only 177 Leks / person, in 2005 was 275 Leks per person and in 2008 amounted to 432 Leks per person. Although this is a modest increase again it shows an improvement of the situation. In 2012 this figure amounted to 338 Leks per capita1.

In 2008, this phenomenon seems to be directed towards higher investments in education. In fact, during the period 2002-2008, it has been a significant increase of the number of pupils and students in Albania. It is also verified a significant increase of private schools in the country, as well as an increase in the number of students studying abroad. These factors correspond to increased spending on education and the increase of the shares to the total real per capita consumption.

The percentage of education with university degree or higher are higher in the fourth and fifth percentile compared with other percentile. Population in the first quintile are mainly with basic education.

Table 3: Highest education level by consumption quintile 


\begin{tabular}{|l|l|l|l|l|l|}
\hline Population aged 21 years and older & Lowest & Second & Third & Fourth & Highest \\
\hline Basic education & $59.7 \%$ & $54.1 \%$ & $50.3 \%$ & $42.3 \%$ & $36.6 \%$ \\
\hline Upper secondary & $30.3 \%$ & $33.1 \%$ & $33.7 \%$ & $36.5 \%$ & $35.7 \%$ \\
\hline University and higher & $4.5 \%$ & $8.1 \%$ & $12.1 \%$ & $17.5 \%$ & $24.9 \%$ \\
\hline
\end{tabular}

The non poor individuals are more involved in the education. The percentage of registration is higher for non poor compared with poor, this for urban and rural population. The percentage of registration is higher for ages 7 to 18 that coresponds with completed the secondary level.

Figure 2: Percentage of registration by area and economic status for individuals aged 6-24 years old, LSMS 2012

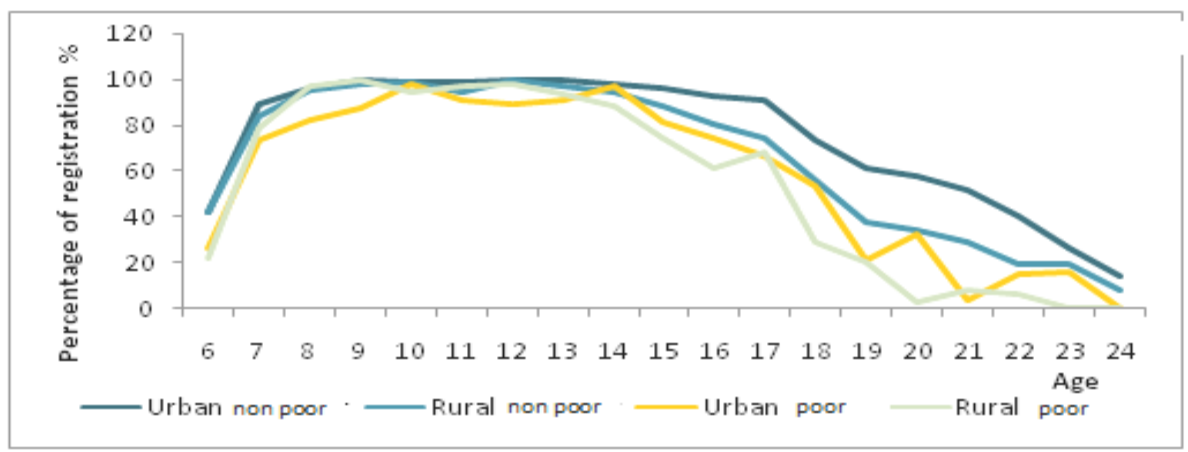

Logistic regression results

The techniques used to identify the contribution of different variables in the analysis of poverty is regression analysis. Regression is a useful technique for testing hypotheses and assess the impact of independent variables on a dependent variable. Special attention should be taken in the selection of independent variables, we must be sure that they are exogenous. Regression models can help us more than other profiles or descriptive analysis of poverty, but they may have problems during estimation and analysis. Based on an extensive econometric literature selected there are some potential problems encountered in linear models, errors in measurement, excluding variables in the model, multicollinearity, heteroskedasticity, remote values, etc. Problems could arise also by the type of the variables included like being dummy or qualitative. Multiple regression model has more than two or more independent variables. In general terms such a model has the form:

$y=\beta_{o}+\beta_{1} x_{1}+\beta_{2} x_{2}+\cdots+\beta_{p} x_{p}+\varepsilon$

$\beta_{0}$ - is intercept or constant, $\beta_{1 \ldots p}$ - parameters of indipendent variables $\mathrm{x}_{\mathrm{i}}$.

Based on the information for the values of dependent variable $Y_{i}$ and the values of dependent variable $X_{i}$, we estimate parameters value $\beta$.

We will use the logarithmic form and taking in consideration the characteristics of the dependent and indipendent variables the regression used will be binary logistic regression. We will use as dependent variable education level. The dependent variable has three category where:

$\mathrm{Y}=1$ secondary, 2-university higher, 0 - no school or just obligatory level

As a reference category 0 -Basic education or none

-Constant,

$\beta_{k}$ - estimated coefficients from model 
$\mathrm{xi}_{\mathrm{i}}$-Predicted or indipendent variables,

\section{$\varepsilon$ - error terms}

Household composition like household size or number of children have an inportant ifluence on the education level. With the increase of the household size the possibility of being in secondary education will be increased sinjificantly. The possibility of being in the university level or higher decreased with increase of household size.

Gender of the head influence significanlty in the possibility to have a high diploma but have non an importand impact on the secondary level.

Geoghraphic division have an important influence on the access of education also in the education level. An individual being in urban area has 3.6 times chances to have at least university diploma compared with rural area and 2.1 times chances to have a secondary diploma.

Being in Tirana region means more acces in basic services and being educated is less coustly. So being in Tirana means more chances to be educated compared with other regions. Being in Mountain region has around $50 \%$ less chances to have at least an university degree diploma.

Health is an important factors influencing social and economic life of the household. Based on the self assesment of the health we conclude that health is an important factors inluencing also the possibility of being educated. Being in good condition have 5.7 times more chances to have a higher education degree and 2.3 times more chances to have a secondary degree compared with other categories. This influence is significantly in $5 \%$ level.

Education is an important dimension of non monetary poverty. Being less educated, have more chances to be poor but also being poor have more chances non being educated. The chances are higher for non poor people to have a university degree or higher (5.73 times). Non poor people have 1.103 times more chances to have secondary diploma compared with poor people. This means that poor people are less educated. This influence is sighnificant in $5 \%$ level.

Table 4: Logistic model of monetary and non monetary poverty

\begin{tabular}{|c|c|c|c|c|c|c|c|}
\hline & \multicolumn{6}{|c|}{ Secondary ediceation } \\
\hline & & $\beta$ & p-value & odds & $\beta$ & $p$-value & odds \\
\hline & Intercept & $-2,743$ & 0,000 & & $-5,150$ & 0,000 & \\
\hline Household size & hhsize & 0.044 & 0,000 & 1.045 & -0.063 & 0,000 & 0.939 \\
\hline \multirow[t]{2}{*}{ Gender of head } & Head male & -0.005 & 0.931 & 0.995 & 0.214 & 0.014 & 1.239 \\
\hline & Head female & & & & & & \\
\hline \multirow[t]{2}{*}{ Gender of person } & Male & 0.245 & 0.000 & 1.277 & 0.056 & 0.235 & 1.058 \\
\hline & Female & & & & & & \\
\hline \multirow[t]{2}{*}{ Area } & Urban & 0.732 & 0.000 & 2.080 & 1.272 & 0.000 & 3.569 \\
\hline & Rural & & & & & & \\
\hline \multirow{2}{*}{$\begin{array}{l}\text { Non monetary } \\
\text { poverty }\end{array}$} & Non poor & 0.648 & 0.000 & 1.911 & 1.409 & 0.000 & 4.092 \\
\hline & Poor & & & & & & \\
\hline \multirow{2}{*}{$\begin{array}{l}\text { No of children } \\
\text { under } 18^{\text {th }}\end{array}$} & No children & 0.875 & 0.000 & 2.400 & 1.062 & 0.000 & 2.893 \\
\hline & At least one child & & & & & & \\
\hline \multirow[t]{4}{*}{ Region } & Coastal & -0.333 & 0.000 & 0.717 & -0.844 & 0.000 & 0.430 \\
\hline & Central & -0.460 & 0.000 & 0.631 & -1.023 & 0.000 & 0.360 \\
\hline & Mountain & -0.399 & 0.000 & 0.671 & -0.700 & 0.000 & 0.497 \\
\hline & Tirana & & & & & & \\
\hline \multirow[t]{2}{*}{ Health perception } & $\begin{array}{l}\text { Good or very } \\
\text { good }\end{array}$ & 0.834 & 0.000 & 2.302 & 1.746 & 0.000 & 5.730 \\
\hline & Average & 0.098 & 0.370 & 1.103 & 0.423 & 0.066 & 1.526 \\
\hline
\end{tabular}


Bad

$\wedge$ Multinominal logistic regression: $Y=1$ secondary, 2-university higher, 0 - no school or just obligatory level, Reference category 0 -Basic education or none

$\wedge \wedge$ Level of significance: ${ }^{* *}$ per $0.001,{ }^{* *}$ per $0.01,{ }^{*}$ per $0.05,+$ per 0.1

\section{Concluding remarks}

Risk of being poor is influenced by education level. Being or not more educated is an important indicator influenced the possibility of finding a good job, well payed but also to the concept of the individuals for a better standard of living, better health service and not being isolated. Education and poverty are factors that influence each other. There are also other important social factors that influence the poverty and as a result education. Education is depended by income/consumption level, by household composition, health status and geographic division.

Being in Tirana have more chances to be educated compared with other regions. Individuals in Tirana has higher mean years of school.

Health perception influence poverty. Individuals that are good or very good have higher education level compared with people that have not good health.

Poverty level influence direct and indirect education. Individuals that are not poor (non monetary) are more educated.

\section{Reference literature}

[1] Alkire, S. and Foster J. (2007): "Counting and Multidimensional Poverty Measurement," OPHI Working Paper Series (7), OPHI. www.ophi.org.uk

[2] Alkire, S. (2009): Multidimensional measures of poverty and well-being" OPHI Working Paper Series

[3] Anderson G., Crawford I., Liecester A. (2005): "Statistical Tests for Multidimensional Poverty Analysis," Brazilia, Brazil: International Conference on the Many Dimensions of Poverty.

[4] Bourguignon, F., Chakravarty, S., (2003). "The measurement of multidimensional poverty”. Journal of Economic Inequality 1, 25-49.

[5] Coudouel, A., Hentschel, J., \& Wodon, Q. (2001). "Well-being measurement and analysis". Poverty reduction strategy sourcebook , nga http://www.worldbank.org.

[6] Dekkers, G. J.M. (2003), "Financial and multidimensional poverty in European Countries: can

[7] the former be used as a proxy of the latter?", IRISS Working Paper Series No. 2003-13

[8] Deutsch J. \& Silber J. (2005). "Measuring Multidimensional Poverty: An Empirical Comparison Of Various Approaches," Review of Income and Wealth.Foster, J. E., Greer J., and Thorbecke E. (1984): "A Class of Decomposable Poverty Measures," Econometrica, 52, 761-766.

[9] Filippone, A., Cheli, B., and D'Agostino, A.(2001) Addressing the Interpretation and the Aggregation Problems in Totally Fuzzy and Relative Poverty Measures, Working Papers of the Institute for Social and Economic Research, paper 2001-22, University of Essex.

[10] Gujarti and Porter (2009). "Basic econometrics". Pp. 553-571.

[11] Lanjouw, P., and M. Ravallion. (1995). "Poverty and Household Size." Economic Journal.

[12] Njong and Ningaye (2008)" Characterizing weights in the measurement of multidimensional poverty: An application of data-driven approaches to Cameroonian data". OPHI Working Paper (21). OPHI.

[13] Nolan, B. and C. Whelan (1996), "Measuring poverty using income and deprivation indicators: Alternative approaches", Journal of European Social Policy, 6(3),

[14] Ravallion M. (1998).."Poverty Lines in Theory and Practice", Living Standards Measurement Study Working Paper No. 133, World Bank. 
[15] Ravallion M. and Bidani B. (1994). "How Robust Is a Poverty Profile?", The World Bank Economic Review.

[16] Ravallion, Martin (1992), "Poverty Comparisons, A Guide to Concepts and Methods", Living Standards Measurement Study, Working Paper 88, World Bank, Washington D.C.

[17] Sen A. "On Economic Inequality". Oxford: Clarendon Press 1973

[18] Silber J. (2007), "Measuring poverty: taking a multidimensional perspective”. Revista de Economía Pública, 182-(3/2007): 29-73

[19] Townsend, P. (1979), "Poverty in the United Kingdom", a Survey of Household Resources and

[20] Standards of Living, London: Penguin Books and Allen Lane

[21] Tsui, K.-Y. (2002): "Multidimensional Poverty indices?" Social Choice and Welfare, 19, 69-93.

[22] Instat, (Shtator 2013), "Trendi i varfërisë në vite 2002-2005-2008-2012". www.instat.gov.al 